\title{
Phytoprotection
}

\section{Identification and documentation of herbicide resistance}

\section{I.M. Heap}

Volume 75, numéro 4, 1994

Herbicide Resistance Workshop - Edmonton, Alberta - 9 and 10 december 1993

Atelier sur la résistance aux herbicides - Edmonton (Alberta) - 9 et 10 décembre 1993

URI : https://id.erudit.org/iderudit/706075ar

DOI : https://doi.org/10.7202/706075ar

Aller au sommaire du numéro

Éditeur(s)

Société de protection des plantes du Québec (SPPQ)l

ISSN

0031-9511 (imprimé)

1710-1603 (numérique)

Découvrir la revue

Citer cet article

Heap, I. (1994). Identification and documentation of herbicide resistance. Phytoprotection, 75(4), 85-90. https://doi.org/10.7202/706075ar

\section{Résumé de l'article}

Les programmes proactifs de gestion de la résistance aux herbicides sont basés sur la détection rapide des populations résistantes et sur la connaissance des combinaisons de mauvaises herbes et d'herbicides prédisposées au développement de cette résistance. Les mauvaises herbes annuelles, prolifiques productrices de graines, génétiquement variées et exposées de façon répétée à des herbicides du même mode d'action, sont sujettes au développement rapide de la résistance. Quand la résistance est soupçonnée, des échantillons de graines sont recueillis et évalués par un bioessai du plant entier. Ces bioessais sont conduits en champ, en chambre de croissance ou en plats de Pétri. Des courbes complètes de réponse aux doses sont tracées en utilisant une population sensible aux herbicides et une population soupçonnée de résistance. Le bioessai conduit en chambre de croissance est la méthode la plus fiable d'identification de nouveaux cas de résistance aux herbicides. Les bioessais basés sur la détection biochimique d'un seul mécanisme de résistance ne sont pas fiables pour la détection de nouveaux cas de résistance.
Ce document est protégé par la loi sur le droit d'auteur. L'utilisation des services d’Érudit (y compris la reproduction) est assujettie à sa politique d'utilisation que vous pouvez consulter en ligne.

https://apropos.erudit.org/fr/usagers/politique-dutilisation/ 


\title{
Identification and documentation of herbicide resistance
}

\author{
$\operatorname{lan}$ M. Heap ${ }^{1}$
}

Received 1993-11-08; accepted 1994-07-11

Proactive herbicide resistance management programs rely upon early detection of resistant populations and knowledge of which combinations of weed and herbicide are prone to the development of resistance. Annual weeds that are prolific seed producers, genetically diverse, and repeatedly exposed to a single herbicide mode of action, are prone to rapid development of resistance. When resistance is suspected, seed samples are collected and evaluated using a whole plant bioassay. Whole plant bioassays are conducted under field, growth room, or Petri dish conditions. Complete dose response curves for the suspected resistant and a reference susceptible population are used to verify resistance. Bioassay, conducted in growth rooms, is the most reliable method for identification of new cases of herbicide resistance. Bioassays, based on the biochemical detection of a single mechanism of resistance, are not reliable for screening for new occurrences of resistance.

Heap, I.M. 1994. Identification et documentation de la résistance aux herbicides. PHYTOPROTECTION 75 (Suppl.): 85-90.

Les programmes proactifs de gestion de la résistance aux herbicides sont basés sur la détection rapide des populations résistantes et sur la connaissance des combinaisons de mauvaises herbes et d'herbicides prédisposées au développement de cette résistance. Les mauvaises herbes annuelles, prolifiques productrices de graines, génétiquement variées et exposées de façon répétée à des herbicides du même mode d'action, sont sujettes au développement rapide de la résistance. Quand la résistance est soupçonnée, des échantillons de graines sont recueillis et évalués par un bioessai du plant entier. Ces bioessais sont conduits en champ, en chambre de croissance ou en plats de Pétri. Des courbes complètes de réponse aux doses sont tracées en utilisant une population sensible aux herbicides et une population soupçonnée de résistance. Le bioessai conduit en chambre de croissance est la méthode la plus fiable d'identification de nouveaux cas de résistance aux herbicides. Les bioessais basés sur la détection biochimique d'un seul mécanisme de résistance ne sont pas fiables pour la détection de nouveaux cas de résistance.

Nomenclature of chemical names cited in the text:

Diclofop-methyl: methyl(土)-2-[4-(2,4-dichlorophenoxy)phenoxy]propanoic acid.

1. Department of Crop and Soil Science, Oregon State University, Corvallis, Oregon, U.S.A. 97331 


\section{INTRODUCTION}

The number of documented cases of herbicide resistance have increased from a few in the early 1970 s to over 100 in 1990 (Holt and LeBaron 1990). Undoubtedly new cases of herbicideresistant weeds, and the area they infest, will continue to increase. Studies on the mechanisms, fitness, and mode of inheritance of resistant populations will advance our general scientific knowledge about the resistance phenomena. Studies on selection pressures, cross-resistance patterns, alternative control measures, and weed population dynamics are immediately useful in developing proactive resistance management programs. In order to manage resistance proactively it is necessary to predict resistance problems, and document herbicide resistance in a scientific and consistent manner when it occurs. This paper describes the characteristics of weed and herbicide combinations that are favorable for the development of resistance, and outlines procedures for identification and documentation of resistance.

\section{CANDIDATES FOR RESISTANCE}

The rapidity of appearance of herbicide resistance is influenced by the characteristics of the weed species, the herbicide, and the usage pattern of the herbicide (Gressel and Segel 1990). Weeds that produce large numbers of genetically different propagules, and that are repeatedly exposed to a single mode of action of herbicide, are the most likely to develop resistance. These are the annual weed species, that are genetically diverse, prolific seed producers, widespread, and problematic to growers if left uncontrolled, such as green foxtail [Setaria viridis (L.) Beauv.], wild oats (Avena fatua L.), wild mustard [Sinapis arvensis (L.)], kochia [Kochia scoparia (L.) Schrad.], Russian thistle (Salsola pestifer Nels.), and chickweed [Stellaria media (L.) Vill.]. Each of these species has developed resistance to one or more herbicide mode of action (Hall and Devine 1989; Heap and Morrison 1992, 1993; Heap et al. 1993; Morrison et al. 1989; Primiani et al. 1990; Saari et al. 1992). Weeds in the Amaranth family, such as redroot pigweed (Amaranthus retroflexus L.) and prostrate pigweed (Amaranthus blitoides S. Wats.) are widespread, genetically diverse, and prolific seed producers, making them likely candidates to follow with resistance to sulfonylurea herbicides.

Herbicides that rapidly select for resistance are highly effective on the weed species (when applied at the recommended rate), and have a single target site mode of action (Gressel and Segel 1990). Examples are herbicides that inhibit the enzyme acetyl coenzymeA carboxylase (ACCase) (aryloxyphenoxypropionates and cyclohexanediones), or those that inhibit the enzyme acetolactate synthase (sulfonylureas and imidazolinones) (Lichtenthaler 1990; Ray 1984).

Repeated usage of herbicides with the same mode of action, without alternative measures of weed control, results in rapid development of resistance (Gressel and Segel 1990). L.ack of effective or economic cultural controls, or herbicides with different modes of action, combined with product loyalty, marketing strategies, and low awareness of the consequences of resistance, have led many farmers into a rapid selection of resistant populations.

\section{INVESTIGATION OF RESISTANCE}

Before conducting expensive trials to determine if a weed has developed resistance, the investigator should determine if the herbicide normally controls the species, if the herbicide was applied correctly (check rates, equipment, application misses, environment, timing etc.), and if the herbicide controlled other susceptible species present at the time of application. If the answer is yes to all these questions, seed samples should be collected and screened for resistance. The herbicide history of the field will assist in deter- 
mining the likelihood that resistance has developed, but the possibility that resistant seed has been imported should not be ignored.

\section{SEED SAMPLING}

\section{Collection}

Seed should be collected from mature, surviving, treated plants, and not from untreated areas. Survivors may be widely dispersed individuals or dense clusters, covering a few square meters to $100 \mathrm{ha}$, thus it is not practical to outline a standard sampling path or frequency. It is important that the seed collected is representative of the population in the area to be tested, whether that area be a few square meters or a whole field. Collection of seed from a single plant will not allow an accurate evaluation of resistance. For most species, the seed sample should be collected from at least 40 mature plants and constitute more than 1000 viable seeds. Collection of seed from larger numbers of plants will increase the accuracy of evaluation of the proportion of resistant individuals in the population. A susceptible population with a similar genetic background to the suspected resistant plants will be needed for comparison, and can normally be obtained from nearby, in an area where herbicides have not been applied.

\section{Identification of sample}

Correct identification of the sample is essential. Identification should include the growers name, address, telephone number, the species collected, the field name, location (map) of the collection site, date of sampling, an outline of the problem, and a detailed crop and herbicide history in the field for the past $10 \mathrm{yr}$.

\section{Handling of sample}

The sample should be dry and kept in paper bags during storage and shipping. Seed samples stored in plastic bags (or any airtight container) are prone to an increase in the incidence of overheating and mold, resulting in a decrease in seed viability.

\section{SCREENING WEEDS FOR HERBICIDE RESISTANCE}

Screening weed populations for herbicide resistance, based on the response of whole plants, has been conducted via field, growth room, and Petri dish bioassays. Biochemical methods, based on extracted enzyme activity in the presence of a herbicide, have also been used to identify specific resistance mechanisms. Gerwick et al. (1993) have reported such a technique for identification of sulfonylurea-resistant broadleaf weeds.

\section{Bioassays}

A susceptible control of the same species must be included for reference, regardless of the type of bioassay. Ideally, this susceptible control should have a similar genetic background to that of the suspected resistant population (usually in the vicinity of the suspected resistant plants where herbicides have not been applied). Where numerous samples $(>100)$ are to be collected and tested for resistance, it is impractical to collect and test a matching susceptible for each. In such cases it is sufficient to test several susceptible populations (never exposed to herbicides) from separate locations to determine the natural variation in levels of tolerance. If this natural variation is relatively small, then one average susceptible population may be used in subsequent bioassays as a reference population. If the variation is large then a susceptible population collected in the same vicinity of each suspected resistant population will have to be used for comparison.

A complete dose-response curve for both the reference susceptible and the suspected resistant populations should be established to determine the level of resistance. An example of such a doseresponse curve is given in Figure 1 (Heap, unpublished data; Brain and Cousens 1989). Levels of herbicide resistance are expressed as the ratio of the $G R_{50}$ for the resistant $(R)$ to the susceptible (S) population $\left(\mathrm{GR}_{50} \mathrm{R}: \mathrm{GR}_{50}\right.$ S). $\mathrm{GR}_{50}$ values are the dosages of herbicide, normally in $\mathrm{g}$ a.i. $\mathrm{ha}^{-1}$, that 


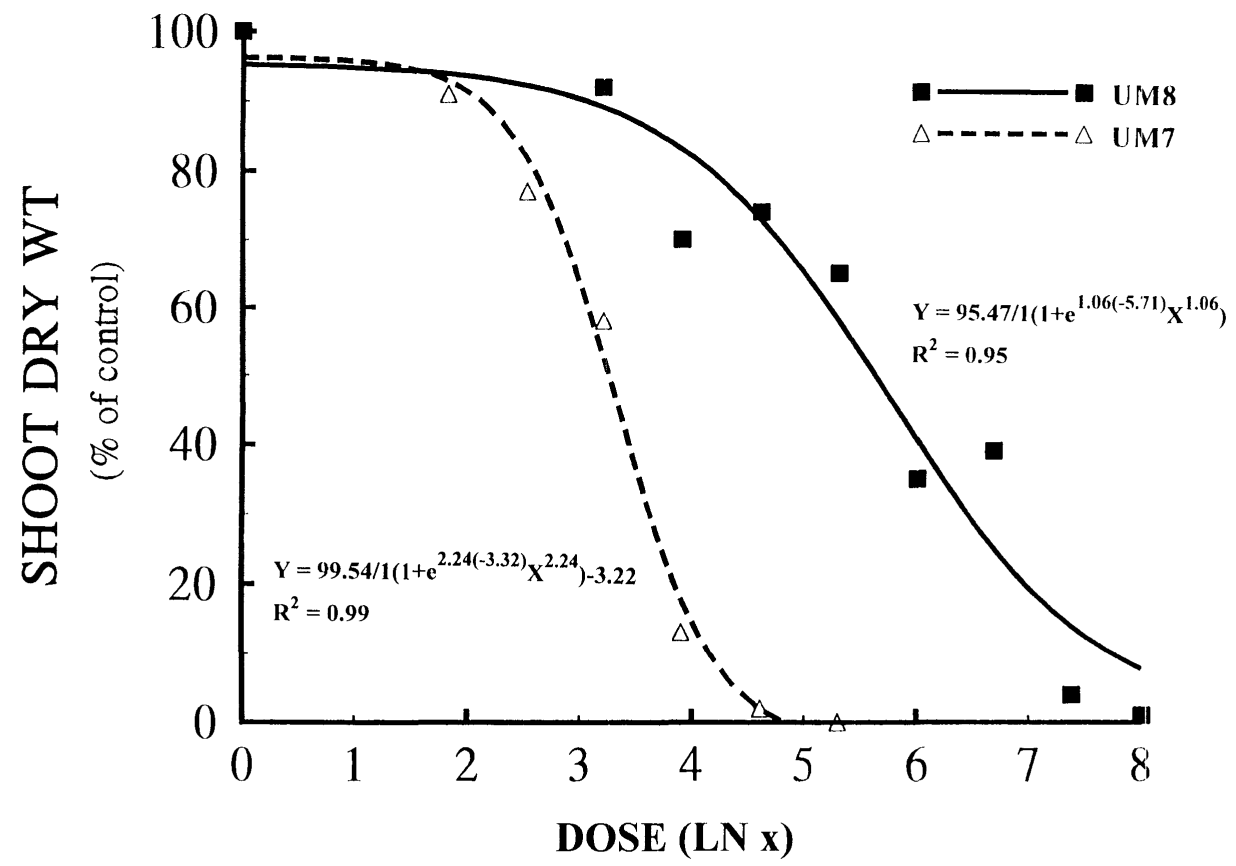

Figure 1. Effect of increasing doses of diclofop-methyl (g a.i. ha-1) on resistant (biotype UM8) and susceptible (biotype UM7) green foxtail shoot growth $21 \mathrm{~d}$ after treatment under growth room conditions. The model fitted was $y=\left(k /\left(1+e^{b g} x^{b}\right)\right)+d(d=l o w e r$ asymptote, $k+d=$ biomass of untreated controls).

reduce shoot dry wt by $50 \%$ relative to untreated controls. Non-linear regression is usually the most appropriate method for establishing the dose at which there is a $50 \%$ reduction in plant dry wt. $\mathrm{GR}_{50}$ and the non-linear function used will vary depending on individual data sets.

\section{Field bioassays}

Unless correctly designed, field tests are not a reliable method of confirming herbicide resistance. There is little point in conducting field trials on the same plants that have survived a herbicide treatment. In this situation there is no reference susceptible population in the field, and the survivors (recovering from the first herbicide application) are likely to be at an advanced leaf stage. Field trials are reliable and very useful if resistant and susceptible seed are sown onto a site not infested with the species being investigated. Then a valid comparison can be made between resistant and susceptible populations over a range of herbicide dosages. This type of field trial can then be used to calibrate laboratory bioassays.

Controlled environment bioassays Growth room and greenhouse bioassays are the most reliable method for identifying herbicide resistance. For this reason, controlled environment bioassays are usually chosen to identify new resistance cases. Unfortunately, these techniques are time consuming and expensive. Seed of susceptible and suspected resistant plants are grown in soil at the optimum temperature and light for the species. Herbicides are applied to seedlings that have reached the recommended growth stage. Plant mortality and reduction in plant growth are recorded several weeks (often three) after the application of the herbicide, and compared to untreated controls. It is essential that a dose response curve for both the reference susceptible and the suspected resistant population is established (Fig. 1) Many herbicides are 
effective at very low dosages under controlled environment conditions, and the recommended field rate may kill both susceptible and resistant populations. The resistance ratio, based on $\mathrm{GR}_{50}$, is more informative than the actual rate required to kill the resistant population.

\section{Petri dish bioassays}

Petri dish bioassays are reliable if they have been correlated with controlled environment or field data. In these assays, the seed or seedling is exposed to intermittent or continuous herbicide solutions, and evaluation is made on seedling mortality and shoot elongation. Petri dish bioassays are most useful for cost effective screening of large numbers of suspected resistant samples, after initial growth room trials have established that resistance to the herbicide occurs.

\section{Biochemical methods}

Biochemical bioassays that screen for specific mechanisms of resistance are not reliable for screening populations suspected of being resistant. Populations of annual ryegrass (Lolium rigidum Gaud.), wild oats and green foxtail vary dramatically in their levels of resistance and patterns of crossresistance to ACCase-inhibitor herbicides (Heap and Knight 1990; Heap and Morrison 1993; Heap et al. 1993). It is likely that there are many different mutations and mechanisms of resistance in these species. For instance, in two ACCase-inhibitor resistant populations of wild oats, one was found to resist diclofop via increased metabolism, whilst the other resisted via an altered plasma membrane response (Devine et al. 1992, 1993). In one population of green foxtail, the mechanism of resistance was due to an alteration of the ACCase enzyme (Marles et al. 1993). It is also likely that some of these mechanisms will be novel, and not just variations of an altered ACCase enzyme, or an increase in metabolism. Any assay that targets detection of a specific mechanism of resistance will miss all other possible mechanisms, known and unknown. Whole plant detection techniques are the only reliable method for detection of new occurrences of resistance.

\section{REFERENCES}

Brain, P., and R. Cousens. 1989. An equation to describe dose responses where there is stimulation of growth at low doses. Weed Res. 29: 93-96.

Devine, M.D., S.A. Maclsaac, M.L. Romano, and J.C. Hall. 1992. Investigation of the mechanism of diclofop resistance in two biotypes of Avena fatua. Pestic. Biochem. Physiol. 42: 88-96.

Devine, M.D., J.C. Hall, M.L. Romano, M.A.S. Marles, L.W. Thomson, and R.H. Shimabukuro. 1993. Diclofop and fenoxaprop resistance in wild oat is associated with an altered effect on the plasma membrane electrogenic potential. Pestic. Biochem. Physiol. 45: 167-77.

Gerwick, B.C., L.C. Mireles, and R.J. Eilers. 1993. Rapid diagnosis of ALS/AHASresistant weeds. Weed Technol. 7: 519524.

Gressel, J., and L.A. Segel. 1990. Modelling the effectiveness of herbicide rotations and mixtures as strategies to delay or preclude resistance. Weed Technol. 4: 186-198.

Hall, L.M., and M.D. Devine. 1989. Cross resistance of a chlorsulfuron resistant biotype of Stellaria media to triazolopyrimidine herbicide. Plant Physiol. 93: 962966.

Heap, I.M., and R.A. Knight. 1990. Variations in herbicide cross-resistance among populations of annual ryegrass (Lolium rigidum) resistant to diclofop-methyl. Aust. J. Agric. Res. 41: 121-128.

Heap, I.M., and I.N. Morrison. 1992. Resistance to auxin-type herbicides in wild mustard (Sinapis arvensis L.) populations in western Canada. Proc. Weed Sci. Soc. Am. 32: 164 (Abstract).

Heap, I.M., and I.N. Morrison. 1993. Resistance to aryloxyphenoxypropionate and cyclohexanedione herbicides in green foxtail (Setaria viridis). Proc. Weed Sci. Soc. Am. 33: 185 (Abstract).

Heap, I.M., B.G. Murray, H.A. Loeppky, and I.N. Morrison. 1993. Resistance to aryloxyphenoxypropionate and cyclohexanedione herbicides in wild oats (Avena fatua). Weed Sci. 41: 232-238.

Holt, J.S., and H.M. LeBaron. 1990. Significance and distribution of herbicide resistance. Weed Technol. 4: 141-149.

Lichtenthaler, H.K. 1990. Mode of action of herbicides affecting acetyl-CoA carboxylase and fatty acid biosynthesis. Z. Naturforsch. 45: 521-528. 
Marles, M.A.S., M.D. Devine, and J.C. Hall. 1993. Herbicide resistance in Setaria viridis conferred by a less sensitive form of acetyl coenzyme-A carboxylase. Pestic. Biochem. Physiol. 46: 7-14.

Morrison, I.N., B.G. Todd, and K.M. Nawolsky. 1989. Confirmation of trifluralin-resistant green foxtail (Setaria viridis) in Manitoba. Weed Technol. 3: 544-551.

Primiani, M.M., J.C. Cotterman, and L.L. Saari. 1990. Resistance of kochia (Kochia scoparia) to sulfonylurea and imidazolinone herbicides. Weed Technol. 4: 169-172.
Ray, T.B. 1984. Site of action of chlorsulfuron. Inhibition of valine and isoleucine biosynthesis in plants. Plant Physiol. 75: 827-831.

Saari, L.L., J.C. Cotterman, W.F. Smith, and M.M. Primiani. 1992. Sulfonylurea herbicide resistance in common chickweed, perennial ryegrass, and Russian thistle. Pestic. Biochem. Physiol. 42: 110-118. 